Religious Individualisation

Volume 1 



\section{Religious Individualisation}

Historical Dimensions and Comparative Perspectives

Edited by

Martin Fuchs, Antje Linkenbach, Martin Mulsow, Bernd-Christian Otto, Rahul Bjørn Parson and Jörg Rüpke

\section{Volume 1}

\section{DE GRUYTER}


This project has received funding from the Deutsche Forschungsgemeinschaft (DFG).

ISBN 978-3-11-058001-3

e-ISBN (PDF) 978-3-11-058085-3

e-ISBN (EPUB) 978-3-11-058093-8

\section{(cc) BY-NC-ND}

This work is licensed under a Creative Commons Attribution-NonCommercial-NoDerivatives 4.0 International License. For details go to http://creativecommons.org/licenses/by-nc-nd/4.0/.

\section{Library of Congress Control Number: 2019939842}

\section{Bibliographic information published by the Deutsche Nationalbibliothek}

The Deutsche Nationalbibliothek lists this publication in the Deutsche Nationalbibliografie; detailed bibliographic data are available on the Internet at http://dnb.dnb.de.

(C) 2019 Fuchs et al., published by Walter de Gruyter GmbH, Berlin/Boston

This book is published open access at www.degruyter.com.

Typesetting: Integra Software Services Pvt. Ltd.

Printing and binding: CPI books $\mathrm{GmbH}$, Leck

Cover image: RakicN / iStock / Getty Images Plus

www.degruyter.com 